\title{
PENGARUH MEDIA WALL CHART TERHADAP KEMAMPUAN MENULIS CERPEN PADA SISWA KELAS XI SMK SWASTA SRI WAMPU PERTUMBUKANTAHUN PEMBELAJARAN 2019/2020
}

\author{
${ }^{1}$ Erlinda Nofasari, S.Pd., M.Pd. \\ ${ }^{2}$ Sri Ulina Beru Ginting,S.Pd.,M.Pd. \\ ${ }^{1,2}$ Dosen STKIP Budidaya Binjai
}

Tujuan dalam penelitian ini yaitu kemampuan menulis cerpen antara kelompok yang diberi pembelajaran dengan menggunakan media wall chart dan kelompok yang diberi pembelajaran menulis teks eksposisi tanpa menggunakan media wall chart, dan pengaruh penggunaan media wall chart dalam pembelajaran menulis cerpen siswa kelas XI SMK Swasta Sri Wampu Pertumbukan. Penelitian ini menggunakan pendekatan kuantitatif dengan metode eksperimen. Desain penelitian yang digunakan adalah Control Group Pretest Postest Design. Variabel dalam penelitian ini ada dua, yaitu variabel bebas yang berupa media wall chart dan variable terikat yaitu kemampuan menulis cerpen. Populasi penelitian ini adalah siswa kelas XI TKJ, XI TSM1 dan XI TSM2 dengan jumlah 109 siswa. Teknik pengambilan sampel adalah simple random sampling. Berdasarkan hasil undian, ditetapkan bahwa kelas XI TSM1 dengan jumlah 36 siswa merupakan kelompok eksperimen dan kelas XI TSM2 dengan jumlah 36 siswa merupakan kelompok kontrol. Teknik pengumpulan data yang digunakan adalah metode tes, yaitu berupa uraian menulis cerpen. Hasil uji normalitas menunjukkan data penelitian ini berdistribusi normal. Hasil uji homogenitas menunjukkan bahwa varian data penelitian ini homogen. Data tersebut selanjutnya dianalisis dengan menggunakan uji-t dan uji scheffe pada taraf siginifikansi 5\% dan db 70. Hasil penghitungan uji-t menunjukkan skor bahwa thitung lebih besar dari tabel (th: 4,711>tt: 1,980) pada taraf signifikansi 5\% dan db 70. Hal ini menunjukkan terdapat perbedaan keterampilan menulis cerpen yang signifikan antara kelompok yang yang diberi pembelajaran dengan menggunakan media wall chart dan kelompok yang diberi pembelajaran tanpa menggunakan media wall chart. Hasil penghitungan uji scheffe menunjukkan F'hitung lebih besar dari F'tabel (Fh: 22,194>Ft: 3,98) dengan db 70 dan pada taraf signifikansi 5\%. Hal ini menunjukkan bahwa pembelajaran menulis cerpen dengan menggunakan media wall chart lebih berpengaruh dari pada pembelajaran menulis cerpen tanpa menggunakan media wall chart pada kelompok kontrol. Jadi, dapat disimpulkan bahwa penggunaan media wall chart dapat meningkatkan kemampuan menulis khususnya menulis cerpen.

Kata kunci: Media Wall Chart, Menulis Cerpen.

\section{PENDAHULUAN}

Pembelajaran

menulis

merupakan salah satu pembelajaran yang memerlukan perhatian khusus baik oleh guru mata pelajaran atau pihak-pihak yang terkait dalam penyusunan kurikulum pembelajaran. Saat ini pembelajaran menulis lebih banyak disajikan dalam bentuk teori, tidak banyak melakukan praktik menulis. Hal ini menyebabkan kurangnya kebiasaan menulis siswa sehingga mereka sulit menuangkan ide mereka dalam bentuk tulisan.

Keterampilan menulis merupakan keterampilan yang perlu dimiliki oleh siswa karena dalam kegiatan pembelajaran di kelas siswa tidak lepas dari kegiatan menulis. Morsey dalam Henry Guntur Tarigan mengemukakan bahwa, "keterampilan menulis merupakan suatu ciri dari orang yang terpelajar atau bangsa yang terpelajar" Menurut Dawson dalam Henry Guntur Tarigan, "salah satu bentuk praktek dan latihan untuk memperoleh penguasaan menulis, dapat dilakukan melalui kegiatan pembelajaran". Jadi, keterampilan menulis itu mengalami proses pertumbuhan melalui latihan. Untuk memperoleh keterampilan menulis tidak cukup dengan mempelajari tata bahasa dan mempelajari 


\section{Jurnal Serunai Bahasa Indonesia \\ Vol 17, No. 2, Oktober 2020 \\ e-ISSN 2621-5616}

pengetahuan tentang teori menulis, melainkan tumbuh melalui proses pelatihan. Keterampilan menulis tidak secara otomatis dikuasai siswa, tetapi melalui latihan dan praktik yang teratur.

Menurut Gail dalam Enny Zubaida, terdapat beberapa jenis tulisan yang juga menentukan siapa pembacanya, salah satu di antaranya adalah tulisan yang berupa cerita".

Salah satu jenis cerita adalah cerita pendek yang sering disingkat cerpen. Cerita pendek merupakan kisahan yang memberikan kesan tunggal yang dominan tentang satu tokoh dalam satu latar dan situasi dramatik; cerpen. Cerita pendek harus memperlihatkan kepaduan sebagai patokan dasarnya.

Menurut Suharianto, "cerpen adalah wadah yang digunakan oleh pengarang untuk menyuguhkan sebagian kecil kehidupan tokoh yang paling menarik perhatian pengarang". Nursito mengemukakan, "cerpen adalah karya yang berisi cerita satu peristiwa dari seluruh kehidupan pelakunya atau cerita yang pendek, namun tidak setiap cerita yang pendek dapat digolongkan ke dalam cerpen". Ismail mengemukakan bahwa, "cerita pendek adalah salah satu ragam fiksi atau cerita rekaan yang sering disebut kisahan prosa pendek". Cerpen adalah cerita fiksi yang bentuknya pendek dan ruang lingkup permasalahannya menyuguhkan sebagian kecil saja dari kehidupan tokoh yang menarik perhatian pengarang, dan keseluruhan cerita memberi kesan tunggal.

Keterampilan menulis yang tidak diimbangi dengan praktik menjadi salah satu faktor kurang terampilnya siswa dalam menulis. Siswa pada sekolah menengah atas seharusnya sudah lebih dapat untuk mengekspresikan gagasan, pikiran, dan perasaannya secara tertulis. Namun pada kenyataannya, kegiatan menulis belum sepenuhnya terlaksana. Siswa tidak mampu menyusun suatu gagasan, pendapat, dan pengalaman menjadi suatu rangkaian berbahasa tulis yang teratur, sistematis, dan logis bukan merupakan pekerjaan mudah, Melainkan pekerjaan yang memerlukan latihan terusmenerus. Menurut Akhadiah, "tidak berlebihan jika dikatakan bahwa kemampuan menulis merupakan kemampuan yang kompleks, yang menuntut sejumlah pengetahuan dan keterampilan".

Melihat fenomena ini, dapat terlihat bahwa kedudukan pelajaran menulis di sekolah-sekolah sangat diperlukan. Salah satu keterampilan menulis tersebut adalah menulis cerpen. Keterampilan menulis cerpen ini bertujuan agar siswa dapat mengekspresikan gagasan, pendapat, dan pengalamnnya dalam bentuk sastra tertulis yang kreatif.

Berkaitan dengan pembelajaran menulis cerpen di SMK yang ternyata belum efektif, maka perlu dicarikan pemecahannya. Pemecahan itulah yang melatarbelakangi penulis melakukan penelitian tentang peningkatan keterampilan menulis cerpen latihan terbimbing pada siswa SMK Swasta Sri Wampu kelas X Pertumbukan Kec. Wampu dipilihnya kelas X SMK Swasta Sri Wampu dikarenakan siswa kelas tersebut dalam pembelajaran menulis cerpen rendah. Selain itu, minat dan antusias yang ditunjukkan selama kegiatan pembelajaran menulis cerpen masih sangat kurang. Hal tersebut mengakibatkan hasil yang diperoleh pada tulisan siswa tidak maksimal.

Media pembelajaran dikelompokan menjadi tiga, yaitu media audio, media visual dan media audio visual. Kualifikasi mengenai media pembelajaran ini telah dikembangkan oleh beberapa ahli. Salah satunya menurut Nana Sudjana dan Plvai, menyatakan bahwa:

Klasifikasi media pembelajaran sebagai berikut:

1. Media Grafis (media dua dimensi), yaitu media yang mempunyai ukuran panjang dan 
lebar. Contoh: gambar, foto, grafik, bagan dan diagram, kartun, komik dan lain-lain.

2. Media tiga dimensi, yaitu media dalam bentuk model seperti model

3. Media proyeksi seperti slide, film strips, film, penggunaan Over Head Projector (OHP) dan lain-lain.

4. Penggunaan lingkungan sebagai media pengajaran.

5. Media Audio.

Dari klasifikasi menurut Nana Sudjana dan Rivai di atas, media gambar termasuk klasifikasikasi yang pertama, dan media gambar merupakan media grafis (media dua dimensi) yang mempunyai ukuran panjang dan lebar. Media gambar digunakan dalam pembelajaran menulis teks laporan hasil observasi, dengan tujuan agar pembelajaran menulis teks laporan hasil observasi dengan menggunakan media gambar dapat menarik. Selain itu digunakannya media gambar dalam pembelajaran bertujuan untuk membuat siswa lebih aktif dalam pembelajaran, karena dengan media gambar siswa dapat melihat secara riil mengenai penjelasan yang guru sampaikan.

Soeparno mengatakan, "Wall chart merupakan suatu media pembelajaran yang dapat berupa gambar, denah, bagan, atau skema yang biasanya digantungkan pada dinding kelas. Kegunaan media ini adalah untuk melatih penguasaan kosakata dan penyusunan kalimat". Media wall chart sering disebut dengan bagandinding karena media ini dapat digantungkan di papan tulis atau di dinding kelas. Salah satu bentuk dari media wall chart yang berupa gambar yaitu cerita gambar. Cerita gambar merupakan gambar semantis yang hampir mirip dengan gambar seri.Bedanya gambar seri merupakan gambar yang merupakan rangkaian cerita, sedangkan carta gambar merupakan gambar gambar yang tidak menggambarkan suatu rangkaian cerita. Misalnya menurut Soeparno, "gambar yang dikelompokkan menurut jenisnya, seperti kelompok gambar benda bernyawa, kelompok benda tak bernyawa, kelompok gambar perbuatan, dan sebagainya".

Menurut Saadie, "wall chart dapat juga berbentuk bagan, bentuk bagan tersebut dapat digambarkan dalam bentuk yang lebih bervariasi seperti: (a) bagan organisasi (aliran) yaitu bagan yang menjelaskan hubungan fungsional antara bagian-bagian dalam suatu organisasi, (b) bagan bergambar (bagan lukis) yaitu bagan yang disampikan dengan gambar atau lukisan, misalnya dalam suatu peta dicantumkan gambar hasil-hasil yang dihasilkan dari daerah tersebut, (c) bagan perbandingan atau perbedaan yaitu bagan yang menunjukkan perbandingan atau perbedaan suatu yang ditujukan dengan lukisan dan katakata, (d) bagan pandang tembus, yaitu bagan yang menerangkan keadaan di dalam suatu benda, (e) bagan keadaan yaitu bagan yang menerangkan keadaan suatu benda dengan bermacam-macam ukuran, (f) bagan terurai, yaitu bagan yang memberikan gambaran seandainya sesuatu diuraikan, tetapi tetap dalam posisi semula".

Wall chart termasuk dalam media visual yang tidak diproyeksikan. Media visual yang tidak diproyeksikan merupakan media yang sederhana, tidak membutuhkan proyektor dan layar untuk memproyeksikan perangkat lunak. Media ini tidak tembus cahaya (nontransparan) maka tidak dapat dipantulkan pada layar. Namun, media ini paling banyak digunakan oleh guru karena lebih mudah pembuatannya maupun penggunaannya. Adanya beberapa faktor seperti, tidak adanya listrik, daerah terpencil, tidak cukup tersedianya dana maupun peralatan, kelompok kelas kecil, menyebabkan guru memilih media yang dirasa praktis dan sederhana. Salah satunya yaitu media wall chart. 


\section{Jurnal Serunai Bahasa Indonesia \\ Vol 17, No. 2, Oktober 2020 \\ e-ISSN 2621-5616}

Pembelajaran dengan menggunakan media wall chart diharapkan dapat menarik perhatian siswa. Selain itu, juga diharapkan media ini dapat mempermudah siswa dalam belajar menulis cerpen serta diharapkan agar proses belajar mengajar dengan menggunakan media wall chart dapat meningkatkan kemampuan menulis cerpen siswa kelas $\mathrm{X}$ SMK Swasta Sri Wampu Pertumbukan sesuai dengan tujuan dalam penelitian ini.

Pembelajaran menulis cerpen, guru dapat menggunakan media wall chart atau bagan dinding untuk memberi gambaran tentang sesuatu sehingga penjelasannya lebih konkret daripada diuraikan dengan kata-kata. Menurut Saadie, "media wall chart sebagai media visual bermanfaat untuk:

(a) Menumbuhkan daya tarik bagi siswa sehingga motivasi menulis siswa meningkat, (b) mempermudah pengertian siswa, (c) memperjelas bagian bagian yang penting, dan (d) menyingkat suatu uraian".

Kegiatan menulis merupakan kegiatan kreativitas untuk menghasilkan karya yang berupa tulisan. Menulis menjadi sebuah pekerjaan dari beberapa orang, dimana mereka menggantungkan hidupnya dari apa yang telah mereka tulis. Walaupun pada awalnya menulis merupakan sebuah hobi bagi kebanyakan seseorang.

Henry Guntur Tarigan, tujuan menulis adalah respons atau jawaban yang diharapkan oleh penulis akan diperoleh dari pembaca. Berdasarkan batasan di atas dapat dikatakan bahwa tujuan menulis adalah sebagai berikut:

\section{Tulisan yang bertujuan untuk memberitahukan atau mengajar disebut wacana informatif,}

2. Tulisan yang bertujuan untuk meyakinkan atau mendesak disebut wacana persuatif,
3. Tulisan yang bertujuan untuk menghibur atau menyenangkan atau yang mengandung tujuan estetik disebut tulisan literer,

4. Tulisan yang mengekspresikan perasaan dan emosi yang kuat atau berapi-api disebut wacana ekspresif.

Hugo Hartig dalam Henry Guntur Tarigan, tujuan menulis meliputi:

1. Tujuan penugasan yaitu menulis karena ditugaskan bukan kemauan

2. Tujuan altruistik yaitu untuk menyenangkan pembaca,

3. Tujuan persuatif, yaitu menyakini pembaca dan kebenaran gagasan yang diutamakan,

4. Tujuan informasional, yaitu memberi informasi kepada pembaca,

5. Tujuan pernyataan diri, yaitu memperkenalkan diri sendiri sebagai pengarang kepada pembaca,

6. Tujuan kreatif, yaitu mencapai nilai-nilai artistik dan nilai-nilai kesenian, dan

7. Tujuan pemecahan masalah, yaitu mencerminkan serta menjelajahi pikiranpikiran agar dimengerti dan diterima oleh pembaca.

Suparno dan Mohammad Yunus mengemukakan beberapa manfaat dari menulis antara lain:

a. meningkatkan kecerdasan,

b.pengembangan daya inisiatif dan kreativitas siswa,

c. penumbuhan keberanian, dan

d. pendorong kemauan dan kemampuan mengumpulkan informasi.

Bernerd Percy melalui Nursito mengungkapkan sekurang-kurangnya ada enam manfaat menulis adalah sebagai berikut.

a. Sarana pengungkapan diri.

b. Sarana untuk memahami sesuatu.

c. Sarana untuk mengembangkan kepuasan pribadi, kebanggaan, dan rasa harga diri. 
d. Sarana untuk meningkatkan kesadaran dan penyerapan terhadap lingkungan sekeliling.

e. Sarana untuk melibatkan diri dengan penuh semangat.

f. Sarana untuk mengembangkan pemahaman dan kemampuan mempergunakan bahasa.

Beberapa manfaat menulis di atas adalah manfaat terperinci dari manfaat secara kesuluruhan. Apabila ditarik garis besar dari manfaat menulis mempunyai manfaat sebagai alat komunikasi yang berupa tulisan, di mana orang dapat memperoleh informasi tidak hanya dari lisan tetapi juga informasi berupa tulisan, serta menulis mempunyai peranan dalam memperluas pengetahuan seseorang dan sebagai wadah dalam menuangkan segala ide, gagasan, ideologi, dan imajinasi yang dimiliki seseorang dan dapat mengembangkan daya inisiatif dan kreativitas, dapat mengatasi trauma, dapat memberikan informasi baru kepada orang lain, membantu kita berpikir secara kritis, dapat menuangkan ide atau gagasan-gagasan kita ke dalam tulisan, dan bisa mempengaruhi pandangan orang lain.

Fungsi menulis adalah untuk menyampaikan informasi kepada pembacanya. Sedangkan parą ahli bahasa telah membagi kembali tentang fungsi menulis.

Rusyana (melalui Isah Cahyani dan lyos, menungkapkan, fungsi menulis dapat dilihat dari dua segi, yaitu segi kegunaan dan perannya dalam menulis cerita.

1. Fungsi menulis dilihat dari segi kegunaan dapat dijelaskan seperti berikut:

(a) Melukiskan: dalam tulisan itu penulis menggambarkan, atau mendeskripsikan sesuatu, baik menggambarkan wujud benda atau mendeskripsikan keadaan sehingga pembaca dapat membayangkan secara jelas apa yang digambarkan atau dideskripsikan penulisnya; (b) Memberi petunjuk: dalam tulisan ini penulis memberikan petunjuk tentang cara melaksanakan sesuatu;

(c) Memerintahkan: penulis memberi perintah, permintaan, anjuran, nasihat, agar pembaca memenuhi keinginan penulis;

(d) Mengingat: penulis mencatat peristiwa, keadaan, keterangan, dengan tujuan mengingat atau hal-hal penting itu tidak terlupakan; dan

(e) Berkorespondensi: dalam tulisan ini penulis melakukan surat menyurat dengan orang lain.

2. Fungsi menulis dilihat dari segi peran dapat diperjelaskan seperti berikut:

(a) Fungsi penataan: pada waktu menulis terjadi penataan terhadap gagasan, pikiran, pendapat, imajinasi, dan penataan terhadap penggunaan bahasa untuk mewujudkan tulisan itu, maka pikiran, gagasan, dan lain-lain diwujudkan secara tersusun.

(b) Fungsi pengawetan: hal-hal yang kita tulis biasanya kita simpan untuk dibaca kembali pada saat yang lain baik oleh para penulis sendiri maupun oleh orang lain;

(c) Fungsi penciptaan: menulis cerita berarti menciptakan sesuatu yang baru di antara gagasan, pikiran, pendapat, atau imajinasi itu mungkin tidak ada sebelumnya atau tidak demikiann susunannya:

(d) Fungsi penyampaian: gagasan, pikiran, imajinasi, itu yang sudah ditata dan diawetkan dalam wujud tulisan dapat dibaca atau disampikan kepada yang lain.

Aktivitas menulis melalui beberapa tahapan, yaitu pramenulis, penulisan, revisi, dan tahap pelaporan (Sabarti Akhadiah, 1997: 78). Keempat tahapan menulis tersebut dapat dijelaskan seperti berikut.

1. Pramenulis

Pada tahap ini seorang penulis melakukan berbagai kegiatan, misalnya menemukan ide, judul karangan, menemukan tujuan, memilih 


\section{Jurnal Serunai Bahasa Indonesia \\ Vol 17, No. 2, Oktober 2020 \\ e-ISSN 2621-5616}

jenis tulisan, dan mengumpulkan bahan tulisan. Ide tulisan dapat bersumber dari pengalaman, observasi, bahan bacaan, dan sebagainya.

\section{Penulisan}

Tahap menulis dimulai dengan menjabarkan ide kedalam bentuk tulisan. Ide-ide itu dituangkan dalam bentuk kalimat dan paragraf. Selanjutnya paragraf-paragraf itu dirangkai menjadi satu karangan yang utuh. Pada tahap ini diperlukan pula berbagai pengetahuan kebahasaan dan teknik penulisan, seperti ejaan, tanda baca, kalimat efektif, diksi,dan paragraf.

\section{Merevisi}

Pada tahap merevisi dilakukan koreksi terhadap keseluruhan karangan. Koreksi dilakukan terhadap berbagai aspek-aspek struktur karangan dan kebahasaan. Struktur karangan meliputi sistematika dan penalaran. Sedangkan, aspek kebahasaan meliputi pilihan kata, struktur, ejaan, dan tanda baca. Tahap revisi masih dimungkinkan perubahan judul

karangan apabila judul tidak sesuai dengan karangan.

\section{Melaporkan}

Pada tahap melaporkan, penulis melaporkan hasil tulisan dalam bentuk cerita atau tulisan tanga.

Proses menulis dalam penelitian ini ada beberapa tahap, yaitu (1) pramenulis: siswa membaca cerita, (2) penulisan: siswa menceritakan kembali secara tertulis, (3) revisi: siswa mengecek hasil tulisan, (4) melaporkan tulisan kepada guru.

Keberhasilan pembelajaran menulis dipengaruhi oleh beberapa faktor, antara lain guru, siswa, teknik pembelajaran, materi pembelajaran, media pembelajaran, evaluasi pembelajaran, dan lingkungan. Guru menganggap dirinya sebagai sumber utama pengetahuan, sehingga teknik ceramah dengan memberikan contoh secara lisan masih menjadi pilihan utama dalam pembelajaran menulis.
Dalam pembelajaran menulis, hendaknya guru menggunakan teknik yang menarik.

Hasil tulisan siswa yang rendah dikarenakan kurangnya minat siswa dalam menulis, kurangnya kreativitas siswa dalam mengembangkan ide yang akan disampaikan, dan kecenderungan siswa ingin menghasilkan tulisan yang panjang tanpa memperhatikan kaidah penulisan. Untuk mengatasi hal tersebut siswa perlu mendapatkan pembelajaran keterampilan menulis secara rutin, seimbang, terpadu, tematis, dan berkesinambungan.

Faktor lain yang menyebabkan rendahnya hasil karangan siswa, yaitu ketidaktepatan pemilihan materi, media, dan evaluasi dalam pembelajaran menulis. Pengembangan bahan ajar menulis dengan berpedoman pada buku paket dan buku pegangan guru merupakan pengembangan yang biasa digunakan guru untuk mengajar. Guru dapat menggunakan kedua bahan ajar tersebut sepanjang dapat menunjang pencapaian kompetensi dasar pembelajaran menulis. Selain itu, guru dapat menggunakan objek yang ada di sekitar siswa maupun sumber dari pembelajaran mata pelajaran lain. Dalam pembelajaran menulis, tampaknya masih sedikit guru yang menggunakan media dalam mengajarkan keterampilan menulis. Sebaiknya guru menciptakan berbagai macam media yang digunakan untuk menggairahkan pembelajaran menulis. Salah satu media pembelajaran yang dapat meningkatkan keterampilan menulis siswa yaitu dengan menggunakan media pop up.

Faktor evaluasi pembelajaran menulis sering juga difokuskan pada menulis tanpa memperhatikan kriteria penilaian yang baik, sehingga hasil penilaian cenderung subjektif. Oleh karena itu, guru harus menggunakan alat evaluasi yang tepat guna dan berdaya guna. Di samping ke enam faktor tersebut ada satu faktor yang mempengaruhi pembelajaran 
keterampilan menulis, yaitu faktor lingkungan. Kondusi lingkungan yang kurang kondusif dan memadai dapat menyebabkan minat belajar siswa kurang. Guru harus memperhatikan hal tersebut guna meningkatkan minat siswa dalam pembelajaran menulis.

Ismail menyebutkan, "cerpen adalah salah satu ragam fiksi atau cerita rekaan yang sering disebut kisahan prosa pendek. Menurut Syarifudin Yunus, "cerpen adalah sebuah cerita yang singkat, padat, dan jelas. Singkat karena cerpen hanya terdiri lebih kurang 10.000 kata, padat karena cerpen memuat peristiwaperistiwa inti dalam cerita, dan jelas karen acerpen memiliki akhir cerita".

Berdasarkan pendapat para ahli di atas dapat disimpulkan bahwa cerpen adalah cerita pendek yang memiliki komposisi lebih sedikit dibanding novel dari segi kependekan cerita, memusatkan pada satu tokoh, satu situasi dan habis sekali baca.

Percy dalam Gie mengemukakan enam manfaat menulis kreatif, yaitu:

(1)suatu sarana pengungkapan diri, seseorang dapat mengungkapkan perasaannya melalui serangkaian kalimat, (2) sebagai sarana pemahaman; ketika menuliskan gagasannya seorang pengarang bisa merenungkan gagasannya dan menyempurnakan pemahamannya terhadap sesuatu hal yang baru atau yang sedang ditulisnya, (3) suatu sarana untuk membantu mengembangkan kepuasan pribadi, kebanggan, dan suatu perasaan harga diri; rasa bangga, puas, dan harga diri merupakan imbalan dari keberhasilan seseorang mengerjakan atau menghasilkan sesuatu, (4) sebagai sarana untuk meningkatkan kesadaran terhadap lingkungan sekitar, (5) sebagai sarana untuk keterlibatan secara bersemangat bukan penerimaan yang pasrah, dan (6) sebagai suatu sarana untuk mengembangkan suatu pemahaman dan kemampuan menggunakan bahasa.
Manfaat menulis menurut Pennebeker dalam Hernowo antara lain,

(1)menjernihkan pikiran, (2) mengatasi trauma, (3) membantu mendapatkan dan mengingat informasi baru, (4) membantu memecahkan masalah, (5) menulis bebas membantu dalam proses menulis. Pendapat tersebut mengisyaratkan bahwa banyak sekali manfaat yang diperoleh dari kegiatan menulis kreatif terutama dari segi psikologis seperti menjernihkan pikiran, mengatasi trauma, dan membantu memecahkan masalah.

Akhadiah dkk. mengemukakan bahwa ada banyak keuntungan yang dapat diperoleh dalam kegiatan menulis, yaitu:

(1)menulis akan membuat seseorang dapat lebih mengenali kemampuan dan potensi dirinya; (2) Ide dalam kegiatan menulis dapat dikembangkan menjadi berbagai gagasan; (3) perlu lebih banyak proses menyerap, mencari, dan menguasai informasi yang sesuai dengan topik yang akan ditulis; (4) menulis berarti mengorganisasikan gagasan secara sistematik serta mengungkapkan secara tersurat; (5) menulis dapat menjadi sarana menilai seseorang dengan lebih objektif; (6) menulis di atas kertas akan lebih memudahkan dalam menyelesaikan masalah dengan menganalisis secara tersurat, dalam konteks yang lebih konkret; (7) tugas menulis tentang sebuah topik dapat mendorong seseorang untuk belajar secara aktif; dan (8) kegiatan menulis yang terencana akan membiasakan berpikir serta berbahasa secara tertib.

Kegiatan menulis sekurang-kurangnya menghasilkan enam jenis nilai, yaitu: 
(1) nilai kecerdasan, dengan sering menulis akan melatih otak untuk sering berpikir kritis sehingga mampu berpikir logis dengan menghubungkan beberapa pemikiran, merencanakan rangka uraian logis dan sistematis, dan menimbang-nimbang sesuatu dengan tepat;

(2) nilai kependidikan, seseorang akan terus terpacu untuk berusaha agar mencapai keberhasilan yang diinginkan;

(3) nilai kejiwaan, dengan menulis akan mendorong seseorang untuk ulet agar menghasilkan tulisan berkualitas agar dapat dimuat di media cetak;

(4) nilai kemasyarakatan, peneliti yang telah berhasil dengan karya-karyanya akan memperoleh penghargaan dalam masyarakat seperti dikenal banyak orang;

(5) nilai keuangan, hasil karya peneliti yang dihargai dengan sejumlah materi jika diterbitkan oleh peneliti;

(6) nilai filsafat, hasil karya pemikiran yang ditinggalkan akan tetap abadi meskipun yang melahirkan pemikiran tersebut telah tiada.

\section{METODOLOGI PENELITIAN}

Penelitian ini akan dilaksanakan di SMK Swasta Sri wampu yang terletak di jalan abadi dusun 2 desa Pertumbukan Kecamatan Wampu, Kabupaten Langkat.. Adapun alasan melakukan penelitian di sekolah ini sebagai berikut:

a. Di sekolah tersebut belum pernah dilakukan penelitian dengan masalah yang sama dengan penelitian ini.

b. Jumlah siswa di sekolah tersebut mencukupi untuk dijadikan subjek penelitian.

\section{Populasi}

Jonathan Sarwono menjelaskan, "populasi adalah sebagai seperangkat unit analisis yang sedang diteliti". Populasi dalam penelitian ini adalah semua siswa kelas XI
SMK Swasta Sri Wampu, yang terdiri dari tiga kelas. XI TKJ, XI TSM1, dan XI TSM2, dengan jumlah siswa sebanyak 109 orang. Data tersebut dapat disajikan pada tabel berikut.

Tabel 1. Data jumlah Populasi

\begin{tabular}{ccc} 
No. & Kelas & Jumlah Siswa \\
\hline 1. & XI TKJ & 37 \\
\hline 2. & XI TSM1 & 36 \\
\hline 3. & XI TSM2 & 36 \\
\hline & JUMLAH & 109
\end{tabular}

\section{Sampel}

Jonathan Sarwono menyatakan, "sampel adalah sub dari seperangkat elemen yang dipilih untuk dipelajarai". Arikunto mengatakan, "Sampel adalah sebagian atau wakil populasi yang diteliti, jika jumlah subjeknya lebih besar dari 100, maka sampel dapat diambil antara 10-15\% atau 20-25\%". Jogiyanto menyatakan, "pengambilan sampel secara cluster random sampling (secara acak) adalah pemilihan sampel dengan membagi populasi menjadi beberapa grup bagian (cluster) dan dari beberapa cluster kemudian dipilih secara random untuk menentukan sampel".

Dari tiga kelas populasi, diambil dua kelas. Sampel yang terpilih adalah kelas XI TSM1 dan kelas XI TSM2. Kedua kelas yang dijadikan sampel diundi lagi untuk menentukan kelas yang diberi perlakuan dan kelas yang tidak diberi perlakuan. Dengan cara diundi memasukan kertas yang berisi tulisan XI TSM1 dan XI TSM2 kedalam botol, lalu menjatuhkan 1 kertas yang dijadikan kelas eksperimen dan kertas kedua adalah kelas kontrol. Kelas yang terpilih sebagai kelas eksperimen adalah kelas XI TSM1 dan kelas yang terpilih sebagai kelas kontrol adalah kelas XI TSM2.

Tabel 2. Data jumlah Sampel

\begin{tabular}{ccc} 
No. & Kelas & Jumlah Siswa \\
\hline 1. & XI TSM1 & 36
\end{tabular}


2.

XI TSM2

JUMLAH

Penelitian ini menggunakan metode eksperimen dengan desain penelitian yang digunakan peneliti adalah kontrol grup pre-tespost-tes.

\begin{tabular}{|c|c|c|c|c|}
\hline & E & $\theta_{1}$ & $\mathrm{X}$ & $\mathrm{O}_{2}$ \\
\hline Keteran & $\mathrm{K}$ & $0_{3}$ & $\mathrm{X}$ & $\theta_{4}$ \\
\hline
\end{tabular}

Dalam desain di atas dapat dilihat pencapaian antara kelompok eksperimen (02 01) dengan pencapaian kelompok kontrol (04 03). Skenario yang dijalankan yaitu XI TSM1 menjadi kelas eksperimen dengan menggunakan media wall chart XI TSM2 sebagai kelas control tanpa menggunakan media wall chart.

Instrumen tes berupa tes subjektif yang berisi perintah kepada siswa untuk menulis cerpen berdasarkan pengalaman orang lain dengan memperhatikan aspek aspek penilaian keterampilan menulis cerpen. Dalam penelitian ini, peneliti menggunakan instrumen berupa tes uraian menulis cerpen dengan media wall chart untuk kelompok eksperimen dan menulis cerpen tanpa media wall chart untuk kelompok kontrol.

Tes menulis cerpen ini berisikan penugasan kepada siswa untuk menulis cerpen. Data yang didapatkan berupa skor yang berasal dari hasil pekerjaan siswa yang telah diukur menggunakan instrumen yang telah dibuat. Instrumen penilaian yang akan digunakan adalah penilaian menulis cerpen. Kisi-kisi soal tes yaitu mengungkapkan gagasan atau ide ke dalam cerpen berdasarkan pengalaman orang lain.

Tabel 3. Aspek Penilaian

\begin{tabular}{|l|l|l|l|l|}
\hline No & Aspek yang Dinilai & Skor & Bobot & Skor X Bobot \\
\hline 1 & Kesestaian tema & 5 & 2 & 10 \\
2 & Penceritaan alur & 5 & 4 & 20 \\
3 & Pemilihan latar & 5 & 4 & 20 \\
4 & Penggunaan sudut pandang & 5 & 2 & 10 \\
5 & Penggunaan gaya bahasa & 5 & 2 & 10 \\
6 & Penggamiaran tokoh dan nenolohan & 5 & 4 & 20 \\
\hline
\end{tabular}

Table 4. pedoman penilaian keterampilan menulis cerpen.

\begin{tabular}{|l|l|l|}
\hline$N_{0}$ & Nilai & Kategori \\
\hline 1 & $85-100$ & Sangat baik \\
\hline 2 & $70-84$ & Baik \\
\hline 3 & $60-69$ & Cukup \\
\hline 4 & 0.59 & Kurang \\
\hline \multicolumn{2}{|c|}{ Teknik pengumpulan data yang } \\
\hline
\end{tabular}
digunakan dalam penelitian ini adalah teknik tes dan teknik nontes. Teknik tes diberikan guna mengetahui data keterampilan menulis menulis cerpen siswa, sedangkan teknik nontes digunakan untuk mengetahui perubahan perilaku siswa setelah proses pembelajaran.

\section{Teknik tes}

Data dalam penelitian diperoleh dengan mengadakan tes sebelum dikenai perlakuan dan setelah proses dikenai perlakuan berupa media wall chart pada kelas XI TSM1 dan pada kelas XI TSM2 tanpa menggunakan media wall chart. Tes dilakukan secara individu berupa penulisan cerpen berdasarkan cerita pengalaman orang lain.

Langkah-langkah dalam pelaksanaan tes yaitu (1) menyiapkan soal tes beserta rubrik penilaian, (2) siswa mencari ide tema berdasarkan permasalahan di sekitarnya, (3) menuangkan ide ke dalam bentuk kerangka cerpen dan selanjutnya dikembangkan menjadi cerpen utuh, dan (4) memberi nilai dan mengolah data hasil penelitian.

\section{Observasi}

Pedoman observasi digunakan untuk mengamati aktivitas siswa selama proses pembelajaran berlangsung. Berikut adalah aspek-aspek yang perlu peneliti amati selama 
proses pembelajaran berlangsung, tedapat beberapa aspek yang diamati dalam observasi yaitu 1) keterbukaan, 2) ketekunan belajar, 3) kerajinan, 4) kedisplinan, 5) kerjasama, 6) ramah dengan teman, 7) hormat dengan guru, 8) kejujuran, 9) tanggung jawab.

Skor untuk masing-masing sikap di atas dapat berupa angka. Skala penilaian dibuat dengan rentangan dari 1-3. Penafsiran angkaangka tersebut adalah sebagai berikut: 1= kurang baik, 2= cukup baik, dan 3= sangat baik.

\section{Dokumentasi}

Teknik dokumentasi dalam penelitian ini bertujuan untuk memperoleh gambar (foto) yang diambil peneliti pada proses pembelajaran berlangsung. Dokumentasi dalam penelitian ini yaitu meliputi kegiatan apersepsi, diskusi kelompok saat mendiskusikan permasalahan yang disajikan, saat siswa menulis cerpen secara individu, dan kegiatan-kegiatan yang dianggap perlu untuk dijadikan sebagai data. Hal ini dimaksudkan sebagai bukti bahwa penelitian pengaruh pembelajaran menulis cerpen dengan menggunakan media wall chart benar-benar dan nyata dilakukan oleh peneliti.

\section{HASIL PENELITIAN DAN PEMBAHASAN}

Penelitian ini bertujuan untuk menguji pengaruh penggunaan media wall chart dalam pembelajaran kemampuan menulis cerpen siswa kelas XI SMK Swasta Sri Wampu Pertumbukan. Data-data penelitian ini diperoleh skor pretes untuk mengetahui kemampuan menulis cerpen awal siswa dan skor postes untuk mengetahui kemampuan menulis cerpen akhir siswa.

Kelompok eksperimen adalah kelompok yang menggunakan media wall chart, sedangkan kelompok kontrol tanpa menggunakan media wall chart. Hasil penelitian kelompok eksperimen dan kelompok kontrol disajikan sebagai berikut.

Kelompok eksperimen merupakan kelas yang diberi pembelajaran dengan menggunakan media wall chart. Sebelum kelompok eksperimen diberi perlakuan, terlebih dahulu dilakukan pretes kemampuan menulis cerpen. Subjek pada pretes kelompok eksperimen sebanyak 36 siswa. Hasil pretes kelompok eksperimen yaitu skor tertinggi sebesar 14 dan skor terendah sebesar 12.

Melalui perhitungan komputer program SPSS versi 16.0 diketahui bahwa skor rata-rata (mean) yang dicapai kelompok eksperimen saat pretes sebesar 13,33; mode sebesar 13,00; skor tengah (median) sebesar 13,00; dan standar deviasi sebesar 0,67612.

Tabel 5
Distribusi Frekuensi Skor Pretes Kemampuan Menulis Cerpen Kelompok
Eksperimen
\begin{tabular}{|c|c|c|c|c|}
\hline Skor & Frekwensi & Frekuensi kumulatif & Frekuensi relatif (\%) & EN \\
\hline 12 & 4 & 36 & 11,12 & 48 \\
\hline 13 & 16 & 32 & 44,44 & 208 \\
\hline 14 & 16 & 16 & 44,44 & 224 \\
\hline
\end{tabular}

Tabel di atas dapat disajikan dalam histogram sebagai berikut.

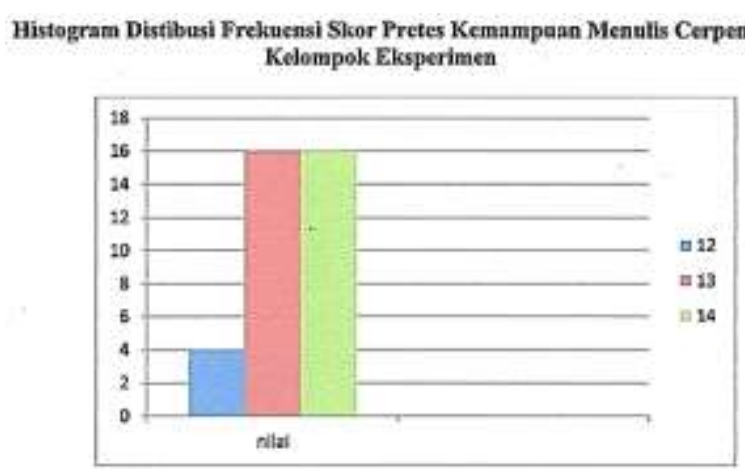

Gambar 1. Distribusi Frekuensi Skor Pretes Kemampuan Menulis Cerpen Kelompok Eksperimen

Berdasarkan tabel dan histogram di atas, dapat diketahui bahwa siswa yang 
mendapat skor 12 ada empat, siswa yang mendapat skor 13 ada enam belas, dan siswa yang mendapat skor 14 ada enam belas.

Kelompok kontrol merupakan kelas yang diberi pembelajaran tanpa menggunakan media wall chart. Sebelum kelompok kontrol diberi perlakuan,

terlebih dahulu dilakukan pretes menulis cerpen. Subjek pada pretes kelompok kontrol sebanyak 36 siswa. Hasil pretes kelompok kontrol yaitu skor tertinggi sebesar 14 dan terendah sebesar 12 .

Melalui perhitungan komputer program SPSS versi 16.0 diketahui bahwa skor rata-rata (mean) pada kelompok kontrol saat pretes sebesar 13,16; mode sebesar 13,00; skor tengah (median) sebesar 13,00; dan standar deviasi sebesar 0,65465 .

Distribusi frekuensi skor pretes kemampuan menulis cerpen kelompok control dapat dilihat sebagai berikut.

Tabel 6

Distribusi Frekwensi Skor Pretes Kemampuan Menulis Cerpen Kelompok Kontrol

\begin{tabular}{|c|c|c|c|c|}
\hline Skor & Frekuensi & Frekuensi kumulatif & Frekuensi relatif(\%) & EN \\
\hline 12 & 5 & 36 & 13.89 & 60 \\
\hline 13 & 20 & 31 & 55.55 & 260 \\
\hline 14 & 11 & $11-$ & 30,56 & 154 \\
\hline
\end{tabular}

Tabel fif atas dupat disajikan dalam bentuk histogram sebagai berikut.

Histogram Distribusi Frelaensi Skor Pretes Kemampuan Menulls Cerpen Kelompok Kostrol

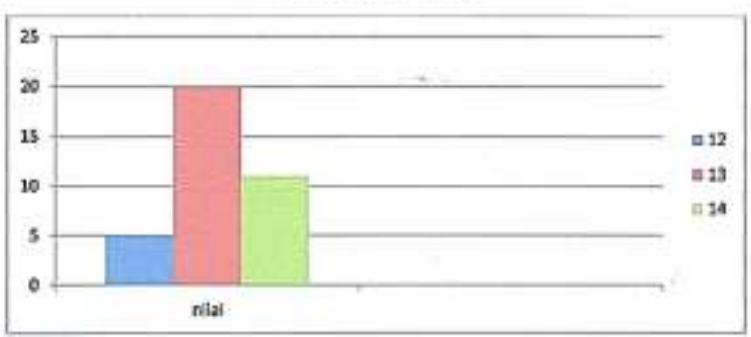

Gambar 2. Distribusi Frekuensi Skor Pretes Kemampuan Menulis Cerpen Kelompok Kontrol
Berdasarkan tabel dan histogram di atas, dapat diketahui bahwa siswa yang mendapat skor 12 ada lima, siswa yang mendapat skor 13 ada dua puluh, dan siswa yang mendapat skor 11 ada sebelas.

Postes kemampuan menulis cerpen pada kelompok ekspreimen dilakukan dengan tujuan melihat pencapaian peningkatan kemampuan menulis cerpen dengan pembelajaran menggunakan media wall chart. Subjek pada postes kelompok eksperimen sebanyak 36 siswa. Hasil postes menunjukkan bahwa skor tertinggi diraih siswa sebesar 17 dan skor terendah sebesar 13.

Melalui perhitungan program SPSS versi 16.0 diketahui bahwa skor rata-rata (mean) yang dicapai kelompok eksperimen saat postes sebesar 15,33; mode sebesar 15,00; skor tengah (median) sebesar 15,00; dan standar deviasi sebesar 1,01419. Distribusi frekuensi skor postes kemampuan menulis cerpen kelompok eksperimen dapat dilihat pada tabel berikut.

Tabel 7

Distribusi Frekuensi Skor Postes Kemampuan Menulis Cerpen Kelompok Eksperimen

\begin{tabular}{|c|c|c|c|c|}
\hline Skor & Frekuensi & Frekuensi kumulatif & Frekuensi relatif (\%) & $\Sigma \mathrm{N}$ \\
\hline 13 & 2 & 36 & 5.55 & 26 \\
\hline 14 & 4 & 34 & 11.12 & 56 \\
\hline 15 & 14 & 30 & 38.88 & 210 \\
\hline 16 & 12 & 16 & 33,33 & 192 \\
\hline 17 & 4 & 4 & 11,12 & 68 \\
\hline
\end{tabular}

Histogram Distribusi Freleesasi Skor Postes Kemampuan Menulis Cerpen Kelompok Elsperimen

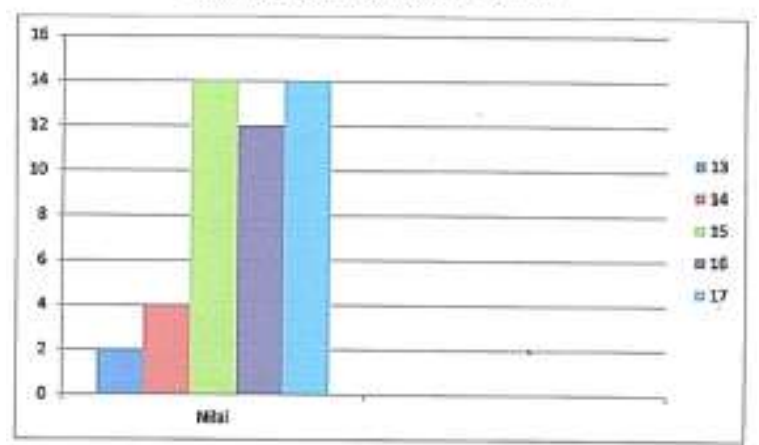


Gambar 3. Distribusi Frekuensi Skor Postest Kemampuan Menulis Cerpen Kelompok Eksperimen

Berdasarkan tabel dan histogram di atas, dapat diketahui bahwa siswa yang mendapat skor 13 ada dua, siswa yang mendapat skor 14 ada empat, siswa yang mendapat skor 15 ada empat belas, siswa yang mendapat skor 16 ada dua belas, dan siswa yang mendapat skor 17 ada empat.

Postes kemampuan menulis cerpen pada kelompok kontrol dilakukan dengan tujuan melihat pencapaian peningkatan kemampuan menulis cerpen dengan pembelajaran tanpa menggunakan media wall chart. Subjek pada postes kelompok kontrol sebanyak 36 siswa. Hasil postes menunjukkan bahwa skor tertinggi diraih siswa sebesar 16 dan skor terendah sebesar 12. Melalui perhitungan program SPSS versi 16.0 diketahui bahwa skor rata rata (mean) yang dicapai kelompok kontrol saat postes sebesar 14,19; mode sebesar 14,00; skor tengah (median) sebesar 14,00; dan standar deviasi sebesar 1,03701. Distribusi frekuensi skor postes kemampuan menulis cerpen kelompok control dapat dilihat pada tabel berikut.

Tabel 8

Distribusi Frekuensi Skor Postes Kemampuan Menulis
Cerpen Kelompok Kontrol
\begin{tabular}{|c|c|c|c|c|}
\hline Skar & Frekuensi & Frekuensi kamulatif & Frehuensi relatif(\%) & IN \\
\hline 12 & 2 & 36 & 5.55 & 2 \\
\hline 13 & 6 & 34 & 16.67 & 78 \\
\hline 14 & 15 & 28 & 41.65 & 210 \\
\hline 15 & 9 & 13 & 25 & 135 \\
\hline 16 & 4 & 4 & 11,12 & 64 \\
\hline
\end{tabular}

Tabel di atas dupat disajikan dalam bentuk histogran sebugai berikut.

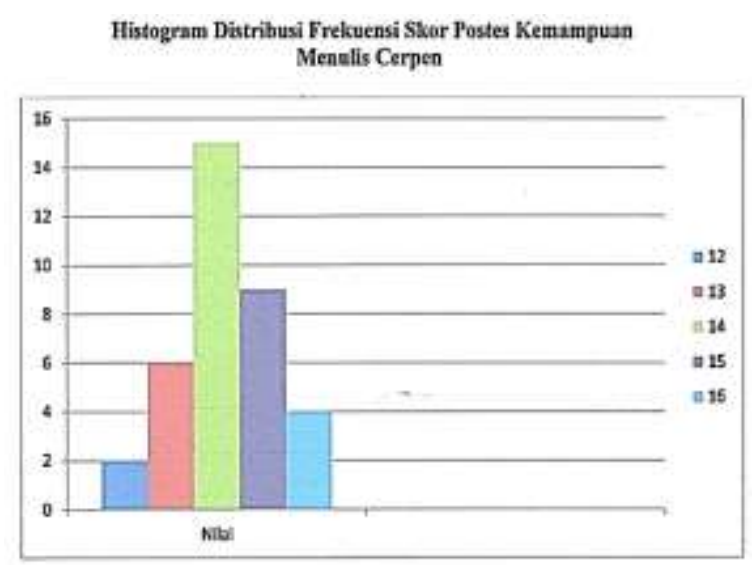

Gambar 4. Distribusi Frekuensi Skor Postest Kemampuan Menulis Cerpen Kelompok Kontrol

Berdasarkan tabel dan histogram di atas, dapat diketahui bahwa siswa yang mendapat skor 12 ada dua, siswa yang mendapat skor 13 ada enam, siswa yang mendapat skor 14 ada lima belas, siswa yang mendapat skor 15 ada sembilan, dan siswa yang mendapat skor 16 ada empat.

Hasil perhitungan normalitas sebaran data pretes kelompok eksperimen diketahui bahwa data tersebut memiliki Asymp. Sig (2tailed $)=0,025$. Berdasarkan hasil tersebut, Asymp. Sig (2 tailed) lebih besar dari 0,05 maka dapat disimpulkan data pretes kelompok eksperimen berdistribusi normal. Hasil perhitungan normalitas sebaran data postes kelompok eksperimen diketahui bahwa data tersebut memiliki Asymp. Sig (2tailed) $=0,098$. Berdasarkan hasil tersebut, Asymp. Sig (2tailed) lebih besar dari 0,05 maka dapat disimpulkan data postes kelompok eksperimen berdistribusi normal.

Hasil penghitungan uji homogenitas varian data pretes dapat diketahui skor hasil tes dari Levene sebeasar 0,970 dan $\mathrm{db} 70$, dan signifikansi 0,328 . Oleh karena signifikannya lebih besar daripada $0,05(5 \%)$, data pretes keterampilan cerpen dalam penelitian ini mempunyai varian yang homogeny atau tidak memiliki perbedaan varian. Hasil uji 
homogenitas varian data postes dapat diketahui skor hasil Levene sebesar 0,006 dan db 70, dan signifikansi 0,941 . Oleh karena signifikannya lebih besar daripada $0,05(5 \%)$, data postes keterampilan menulis cerpen dalam penelitian ini mempunyai varian yang homogen atau tidak memiliki perbedaan varian.

Hasil analisis diperoleh besarnya $\mathrm{t}$ hitung adalah 4,711 dengan db 70. Nilai thitung tersebut dikonsultasikan dengan nilai $\mathrm{t}$ tabel pada taraf siginifikansi 5\% dan db 70 . Nilai ttabel pada taraf signifikansi $5 \%$ dan $\mathrm{db}$ 70 yaitu 1.980. Nilai p diperoleh sebesar 0,00. Jadi th ( thitung) lebih besar dari tt (ttabel) dan nilai $p$ lebih kecil dari 0,05 . Hasil uji-t tersebut menunjukkan bahwa kemampuan menulis cerpen antara kelompok kontrol dan kelompok eksperimen memiliki perbedaan yang signifikan. Hasil selengkapnya dapat dilihat pada lampiran 9.

Berdasarkan data di atas, diperoleh simpulan: (1) skor pretes kemampuan menulis cerpen antara kelompok kontrol dan kelompok eksperimen menunjukkan bahwa tidak ada perbedaan yang siginifikan; (2) skor pretes dan postes kemampuan menulis cerpen kelompok kontrol menunjukkan bahwa tidak perbedaan yang siginifikan; (3) skor pretes dan postes kemampuan menulis cerpen kelompok eksperimen menunjukkan bahwa ada perbedaan yang signifikan; (4) skor postes kelompok kontrol dan kelompok eksperimen menunjukkan bahwa ada perbedaan yang siginifikan.

Uji scheffe dalam penelitian ini bertujuan untuk mengetahui pengaruh penggunaan media wall chart pada kegiatan menulis cerpen pada kelompok eksperimen. Penghitungan uji scheffe dilakukan dengan bantuan SPSS versi 16.0. Syarat data dikatakan signifikan apabila skor F'hitung (Fh) lebih besar dari F'tabel $(\mathrm{Ft})$.
Dari tabel di atas diketahui bahwa skor F'hitung (Fh) sebesar 22,194 dengan db 70 dan p sebesar 0,000 skor tersebut dikonsultasikan dengan skor F'tabel $(\mathrm{Ft})$ dengan $\mathrm{db} 1><70$ ada taraf signifikansi 5\% sebesar 3,98. Dengan demikian skor F'hitung lebih besar daripada F'tabel (F'h: 22,194>F't: 3,98).

Dengan demikian hasil uji scheffe tersebut menunjukkan bahwa penggunaan media wall chart berpengaruh digunakan dalam pembelajaran menulis cerpen.

Perhitungan berdasarkan rumus statistik uji-t antar kelompok dengan bantuan komputer SPSS versi 16.0 diperoleh t'hitung sebesar 4,711 dengan db 70. Kemudian skor thitung dikonsultasikan dengan nilai tabel pada taraf signifikansi 5\% dan db 70 adalah 1,980. Hal itu menunjukkan bahwa skor t'hitung lebih besar dari skor t'tabel. Dengan demikian, hipotesis nihil (Ho) yang menyatakan tidak ada perbedaan antara kelompok siswa yang diberi pembelajaran kemampuan menulis cerpen menggunakan media wall chart dengan kelompok siswa yang diberi pembelajaran tanpa menggunakan media wall chart ditolak. Sementara itu, hipotesis alternatif (Ha) yang menyatakan ada perbedaan kemampuan menulis cerpen antara kelompok siswa yang diberi pembelajaran menggunakan media wall chart dengan kelompok siswa yang diberi pembelajaran tanpa menggunakan media wall chart diterima.

Hipotesis kedua dalam penelitian ini adalah pembelajaran kemampuan menulis cerpen dengan menggunakan media wall chart lebih efektif dibandingkan pembelajaran kemapuan menulis cerpen tanpa menggunakan media wall chart $(\mathrm{Ha})$.

Perhitungan berdasarkan rumus statistik uji scheffe dengan bantuan komputer SPSS versi 16.00 diperoleh F'hitung sebesar 22,194 dengan $\mathrm{db}$ 70. Kemudian skor F'hitung dikonsultasikan dengan nilai F'tabel pada taraf 
signifikansi 5\% dengan db 70 adalah 3,98. Hal itu menunjukkan bahwa F'hitung lebih besar dari F'tabel. Dengan demikian, hipotesis nihil (Ho) yang menyatakan pembelajaran menulis cerpen dengan menggunakan media wall chart tidak efektif dibandingkan pembelajaran menulis cerpen tanpa menggunakan media wall chart ditolak. Sementara itu, hipotesis alternative (Ha) yang menyatakan pemebelajaran kemampuan menulis cerpen dengan menggunakan media wall chart lebih efektif dibandingkan pembelajaran kemampuan menulis cerpen tanpa menggunakan media wall chart diterima.

\section{Pembahasan Hasil Penelitian}

Penelitian ini dilakukan di SMK Swasta Sri Wampu Pertumbukan. Populasi dalam penelitian ini adalah kelas XI. Sampel dalam penelitian penelitian ini berjumlah 72 siswa dengan rincian 36 siswa sebagai kelompok kontrol dan 36 siswa sebagai kelompok eksperimen. Tujuan penelitian ini adalah untuk mengetahui perbedaan kemampuan menulis teks eksposisi antara kelompok yang diberi pembelajaran dengan menggunakan media wall chart dan kelompok yang diberi pembelajaran tanpa menggunakan media wall chart dalam pembelajaran menulis cerpen siswa kelas XI SMK Swasta Sri Wampu Pertumbukan.

\section{Deskripsi Kondisi Awal Keterampilan Menulis Cerpen Kelompok Kontrol dan Kelompok Eksperimen}

Kondisi awal kedua kelompok dalam penelitian ini diketahui dengan melakukan pretes keterampilan menulis cerpen. Peneliti mengumpulkan data menggunakan instrumen penelitian berupa pedoman penyekoran tes menulis cerpen. Dari hasil pengumpulan data tersebut diperloleh skor pretes kelompok kontrol dan kelompok eksperimen. Skor tertinggi yang dicapai kelompok eksperimen adalah 14 dan skor terendah 12 dengan skor rata-rata (mean) sebesar 13,33; mode sebesar
13,00; skor tengan (median) 13,00; dan standar deviasi sebesar 0,68. Skor tertinggi yang dicapai kelompok eksperimen adalah 14 dan skor terendah sebesar 12 dengan skor rata-rata (mean) sebesar 13,16; mode sebesar 13,00; skor tengah (median) sebesar 13,00; dan standar deviasi sebesar 0.65 dari hasil tersebut dapat diketahui bahwa skor tes menulis cerpen kelompok eksperimen dan kelompok kontrol masih rendah.

\section{PENUTUP}

\section{A. Kesimpulan}

Berdasarkan hasil penelitian dan pembahasan yang telah disampaikan, maka dapat diambil kesimpulan sebagai berikut.

1. Terdapat perbedaan yang signifikan keterampilan menulis cerpen siswa kelompok eksperimen yang mendapat pembelajaran dengan menggunakan media wall chart dan kelompok kontrol yang tidak mendapat pembelajaran dengan menggunakan media wall chart pada pembelajaran menulis teks eksposisi perbedaan kemampuan menulis cerpen tersebut ditunjukkan dengan hasil uji-t postes kelompok eksperimen dan postes kelompok kontrol yaitu hasil penghitungannya yang menunjukkan bahwa skor hitung lebih besar dari skor tabel (th: 4,711>tt: 1980) pada taraf signifikansi 5\% dan $\mathrm{db}$ 70. Siswa yang diberi pembelajaran dengan menggunakan media wall chart dalam menulis cerpen lebih bagus dibandingkan siswa yang diberi pembelajaran tanpa menggunakan media wall chart.

2. Penggunaan media wall chart dalam pembelajaran menulis teks eksposisi lebih efektif dibandingkan pembelajaran tanpa menggunakan media wall chart. Pengaruh penggunaan media wall chart terhadap keterampilan menulis cerpen ditunjukkan dengan hasil uji scheffe, yaitu F'hitung lebih besar daripada skor F'tabel (Fh: 22,194>Ft: 3,98) dengan db 70 pada taraf signifikansi 5\%. 
Dengan demikian hasil uji scheffe tersebut menunjukkan bahwa terdapat perbedaan keterampilan menulis cerpen yang signifikan antara kelompok eksperimen yang menggunakan media wall chart dengan kelompok kontrol yang tidak menggunakan media wall chart dalam pembelajaran menulis cerpen. Hal ini menunjukkan bahwa pembelajaran menulis cerpen dengan menggunakan media wall chart lebih efektif dari pada pembelajaran menulis cerpen tanpa menggunakan media wall chart.

\section{B. Saran}

Berdasarkan kesimpulan di atas, maka saran dari hasil penelitian ini adalah sebagai berikut.

1. Perlu diadakan penelitian selanjutnya untuk mengetahui pemanfaatan media wall chart dalam pembelajaran menulis cerpen dengan populasi yang lebih luas.

2. Media wall chart dapat dijadikan salah satu alternatif untuk meningkatkan keterampilan menulis, khususnya menulis cerpen.

\section{DAFTAR PUSTAKA}

Abdul Rani Supratman. 2004. Intisari Sastra Indonesia. Bandung : Pustaka Setia.

Azhar Arsyad. 2015. Media Pembelajaran. Jakarta: Pt Raja Gravindo Persada.

A. Widyamartaya. 1993. Seni Menuangkan Bahasa. Yogyakarta: Kanisius.

Burhan Nurgiyantoro. 2001. Penilaian Dalam Pembelajaran Bahasa dan Sastra. Yogyakarta: BMFE.

Departemen Pendidikan Nasional. 2000. Kamus Besar Bahasa Indonesia. Jakarta : Balai Pustaka.
Daryanto. 2010. Media Visual Untuk Pengajaran Teknik Bandung: Tarsito.

Diah Erna Triningsih. 2010. Gaya Bahasa dan Peribahasa dalam Bahasa Indonesia. Klaten: PT Intan Pariwara.

Enny Zubaidah. 2012. "Peningkatan Kemampuan Mahasiswa dalam MenulisCerita Anak melalui Strategi Menulis Terbimbing. Jakarta: Program Pasca Sarjana Univeristas Negeri Jakarta.

Fahrudin Enre. Dasar-dasar Keterampilan Menulis. Jakarta: Depdikbud.

Ginting, Sri Ulina.2019. Peningkatan Keterampilan Menulis Cerpen Melalui Media Lagu “ Elegi Esok Pagi” Karya Ebid.G.Ade Siswa Kelas XI SMA Swasta Nasional Namotrasi Tahun Pelajaran 2018/2019. Jurnal Serunai Bahasa Indonesia 16.(2) oktober 2019.

Gunarsa, S.D., dan Gunarsa, Y.S.D. 1985. Psikologi Perkembangan Anak dan Remaja, Cet. 2. Jakartą : Penerbit PT. Multindo Auto Finance. BPK. Gunung Mulia.

Gorys Keraf. 2010. Diksi dan Gaya Bahasa (Jakarta: PT Gramedia Pustaka Utama.

Haryadi dan Zamzani. 1996. Peningkatan Keterampilan Berbahasa Indonesia.

Yogyakarta: Depdikbud Dirjen Dikti Bagian Proyek Pengembangan Pendidikan Guru Sekolah Dasar.

Henry Guntur Tarigan. 1984. Menulis Sebagai Suatu Keterampilan Berbahasa. Bandung: Angkasa.

Harjito. 2002. Sastra dan Manusia : Teoridan Terapannya. Semarang : IKIP PGRI. 
Hernowo. 2004. Mengikat Makna Untuk Remaja. Bandung: MLC.

Isah Cahyani \& Iyos Ana Rosmana. 2006. Pendidikan Bahasa Indonesia. Bandung: UPI Press.

Ismail Muhaimin. 2001. Menulis Secara Populer. Jakarta : Pustaka Jaya.

Jonathan Sarwono. 2006. Metode Penelitian Kuantitatif \& Kualitatif. Yogyakarta : Graha Ilmu.

Jacob Sumardjo. 2007. Catatan Kecil Tentang Menulis Cerpen. (Yogyakarta: Pustaka Pelajar.

M. Atar Semi. 1993. Menulis Efektif. Padang: Angkasa Raya.

Moenir, A.S. 2008. Manajemen Pelayanan Umum di Indonesia. Jakarta: Bumi Aksara.

Mursal Esten. 2000. Teori Kesusasteraan Pengantar Teori dan Sejarah. Yogyakarta : Kanisius

Nana Sudjana dan Ahmad Rivai. 2007. Media Pengajaran. Bandung: Sinar Baru Algesindo.

Nursisto. 1999. Penuntun Mengarang. Yogyakarta: Adicita Karya Nusa. Puja Laksana. (2009). Panduan Praktis Mengarang-Menulis. Semarang: Aneka Ilmu.

Raman Tinambunan T. 1996. Sastra Lisan Dairi : Inventarisasi Dan Analisis

Struktur Prosa. Jakarta : Depdikbud. Pusat Pembinaan dan Pengembangan Bahasa.

The Lian Gie. 2002. Terampil Mengarang. Yogyakarta: Andi. Sabarti Akhadiah, dkk. 1991. Bahasa Indonesia I. Jakarta: Depdikbud.
Suminto A Sayuti. 2000. Berkenalan dengan Prosa Fiksi. Yogyakarta: Gama Media.

Suharianto, S. 2008. Dasar-dasar Teori Sastra. Semarang :Rumah Indonesia.

Suharsimi Arikunto. 2010. Prosedur Penelitian Suatu Pendekatan Praktik. Jakarta: PT Rineka Cipta.

Suparno dan Muhammad Yunus. 2007. Keterampilan Dasar Menulis. Jakarta: Universitas Terbuka.

W.J.S. Poerwadarminta. 1984. Kamus Umum Bahasa Indonesia. Jakarta: Balai Pustaka.

Wikipedia. Kemampuan, di unduh tanggal 7 Maret 2019 pukul 20.00 Wib.

Yunus, Syarifudin. 2015. Kompetensi Menulis Kreatif. Bogor: Ghalia Indonesia.

Zainuddin. 1991. Materi Pokok Bahasa dan Sastra Indonesia. Jakarta: Rineka Cipta. 